\title{
ADENOVIRUS RESPIRATORY INFECTION: SIGNIFICANT INCREASE IN DIAGNOSIS USING PCR COMPARING WITH ANTIGEN DETECTION AND CULTURE METHODS
}

Elenice STROPARO(1), Cristina R. CRUZ(2), Maria do Carmo DEbUR(3), Luine R. VIDAL(3), Meri B. NOGUEIRA(3), Sergio M. de ALMEIDA(3), Luciane A. PEREIRA(3), Indianara ROTTA(3) \& Sonia Mara RABONI(3,4)

\begin{abstract}
SUMMARY
Adenovirus (AdV) respiratory infections are usually described as being associated with high mortality rates. Laboratory diagnosis is essential for the establishment of the appropriate therapy, and for guiding the implementation of preventive measures in order to prevent the spread of the infection. Aiming to analyze the sensitivity and specificity of the laboratorial diagnosis methods available, we compared antigen detection by indirect immunofluorescence assay (IF), and a specific nested polymerase chain reaction (PCR), to detect $\mathrm{AdV}$ in respiratory samples collected from patients admitted to hospital with acute respiratory disease. Positive samples were inoculated into a cell culture to confirm the results. We analyzed 381 samples from the nasopharyngeal aspirates collected during the year 2008; of these, $2.6 \%$ tested were positive for adenovirus through IF and 10\% through PCR; positive isolation was obtained in $40 \%$ and $26 \%$ of these cases, respectively. Most infected patients were children under six months of age, and despite of the fact that a significant number of patients required intensive care, the mortality rate was low (5\%). In conclusion, molecular methods were found to be useful for rapid diagnosis of adenovirus infections with higher sensitivity than antigen detection; their introduction permitted a significant increase in diagnoses of adenovirus infections.
\end{abstract}

KEYWORDS: Adenoviruses; Polymerase chain reaction; Diagnosis; Pediatric patients; Immunocompromised patients; Acute respiratory infections.

\section{INTRODUCTION}

Human adenoviruses are responsible for various different clinical syndromes, including gastroenteritis, respiratory disease, conjunctivitis, hemorrhagic cystitis and exanthema ${ }^{11,18}$. There are 51 known immunologically distinct AdV serotypes that can infect humans, which are grouped into six species (formerly called subgenera) A to F, based on the relative nucleic acid homology, fiber protein characteristics and other biochemical and biological properties ${ }^{6}$, which differ in tissue tropism and patterns of disease ${ }^{30}$. This subdivision has some clinical relevance, as distinct AdV species show a preference for specific organs: $\mathrm{C}, \mathrm{E}$ and some B species typically infect the respiratory tract; other B species infect the urinary tract; species A and F target the gastrointestinal tract; and species $\mathrm{D}$, the eyes ${ }^{19}$. The degree of severity of the disease caused by AdV also depends on the age and immune status of the infected individual; although a variety of other social and physical factors may also cause more severe disease. In immunocompetent patients, $\mathrm{AdV}$ is responsible for several acute, usually self-limited diseases, as well as persistent infection ${ }^{3}$. The disease may vary from mild to severe, disseminated, or fatal; the overall fatality rate is between $18 \%$ and $26 \%{ }^{17}$. Despite its relatively common occurrence in infants and young children, fatal pneumonia can occur in healthy adults. In immunocompromised patients, $\mathrm{AdV}$-associated case fatality rates have been reported to be as high as $60 \%$ in patients with pneumonia and $50 \%$ in those with hepatitis, compared to fatality rates of $15 \%$ for pneumonia and $10 \%$ for hepatitis in immunocompetent patients ${ }^{15}$. Infection is far more severe in the immunocompromised population, with a case mortality rate as high as $80 \%$ in hematopoietic stem cell transplant (HSCT) recipients ${ }^{26}$.

The diagnosis of AdV disease has traditionally been performed using antigen detection by indirect immunofluorescence and culture-based techniques. Viral antigen detection of respiratory viruses is useful for most respiratory viruses, but this methodology has a lower sensitivity than cell culture for the diagnosis of AdV. While effective at detecting end-organ infection in symptomatic patients, cell culture lacks the sensitivity for detecting low levels of circulating viruses, and may require weeks to deliver definitive results ${ }^{14}$. Molecular diagnostic assays offer advantages in terms of speed, sensitivity and the ability to quantify viruses $^{7}$ and improved methods of diagnosis are needed partucularly in immunocompromised patients ${ }^{21}$. They have been particularly useful for the $\mathrm{AdV}$ detection in peripheral blood - a finding that has been correlated with the risk of progression to disseminated disease in HSCT patients

(1) Programa de Pós-Graduação em Saúde da Criança e do Adolescente, Universidade Federal do Paraná. Curitiba, Paraná, Brasil.

(2) Departamento de Pediatria, Universidade Federal do Paraná, Curitiba, Paraná, Brasil.

(3) Laboratório de Virologia, Hospital de Clínicas da Universidade Federal do Paraná. Curitiba, Paraná, Brasil.

(4) Disciplina de Doenças infecciosas, Universidade Federal do Paraná, Curitiba, Paraná, Brasil.

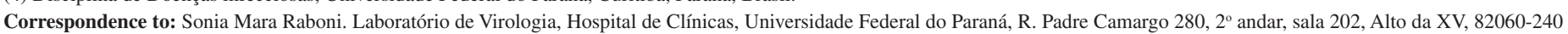

Curitiba, PR, Brasil. E.mail: sraboni@ufpr.br 


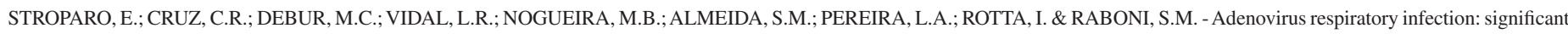
increase in diagnosIs using PCR comparing with antigen detection and culture methods. Rev. Inst. Med. Trop. Sao Paulo, 52(6): 317-21, 2010.

infected with $\mathrm{AdV}^{8,27}$. In addition, the ability to monitor viral load offers potential for monitoring responsiveness to antiviral therapy, which is becoming more practical ${ }^{29}$. However, the paucity of treatment options to control these infections emphasizes the urgent need for well-controlled clinical trials of the currently developed therapeutic modalities ${ }^{16}$.

The present study has two purposes: to compare antigen detection and PCR method for the diagnosis of AdV infections in patients hospitalized due to acute respiratory infection, and to report on the clinical and epidemiological findings in $\mathrm{AdV}$ infected pediatric patients.

\section{MATERIAL AND METHODS}

Clinical specimens: We conducted a prospective, descriptive and cross-sectional study. Nasopharyngeal aspirates (NPA) collected from children and immunosuppressed patients with acute respiratory infections hospitalized at the Hospital de Clínicas/Universidade Federal do Paraná (HC-UFPR) in 2008 were assessed. After collection and the addition of transport medium, samples were sent to a virology laboratory and immediately processed. First, they were centrifuged at 1,500 g for 10 to 15 minutes at $4{ }^{\circ} \mathrm{C}$. The supernatant was separated into two portions: one to be used for virus isolation in cell culture and one for molecular biology tests (PCR). Additionally, cells in the sediment were washed and placed on glass slides, fixed in cold acetone for 10 minutes, and processed for indirect immunofluorescence assay (IF).

Indirect immunofluorescence assays (IF) on respiratory samples: Detection of viruses (respiratory syncytial virus - RSV, influenza A - FLUA, influenza B - FLUB, AdV, and parainfluenza group viruses - PIV) in cells shed into the respiratory tract was performed by IF as previously reported ${ }^{28}$, using commercially available monoclonal antibodies (Chemicon International Inc.,Temecula, CA), according to the manufacturer's suggestions.

The slides were examined in a fluorescence microscope with epiillumination. All clinical specimens were read by two observers. Samples that seemed doubtful or discrepant were read at least twice to check for reproducibility. Samples have indeterminate results when it was impossible to define the presence or absence of fluorescent cells, due to unspecific coloration (background).

PCR: DNA extraction was performed following the method previously reported by CASAS et al. $(1995)^{4}$, based on guanidinium thiocyanate extraction and isopropanol precipitation. The PCR method used, specific to AdV, was the nested PCR, and primers were designed within the hexon protein gene of the $\mathrm{AdV}$ genome, capable of detecting the DNA of 51 types of human AdV in a wide range of clinical samples, reported by AVELLÓN et al. $(2001)^{1}$. The PCR reaction was performed following the guidelines previously reported with some modifications. Briefly, the amplification was carried out with $2.5 \mu \mathrm{L}$ DNA extracted in a $25 \mu \mathrm{L}$ reaction mixture containing $10 \mathrm{x}$ Buffer, $1.5 \mathrm{mM} \mathrm{MgCl} 2$, $0.2 \mathrm{mM}$ dNTP's (Boehringer, Mannheim, Germany), 10 pmol of each primers (ADHEX 1F and ADHEX 2R) and $1 \mathrm{U}$ of Taq DNA polymerase (Invitrogen, Inc, California, USA) for the first reaction. The mixtures were overlaid and 30 cycles of amplification were performed in a thermocycler. Each cycle consisted of denaturation for $60 \mathrm{~s}$ at $94^{\circ} \mathrm{C}$, annealing for $60 \mathrm{~s}$ at $50{ }^{\circ} \mathrm{C}$, and primer extension for $60 \mathrm{~s}$ at $72{ }^{\circ} \mathrm{C}$. In the first cycle, the denaturation step was for two min at $94^{\circ} \mathrm{C}$ and elongation was extended to six min. For the nested reaction, $1 \mu \mathrm{L}$ of primary amplification product was added to $24 \mu \mathrm{L}$ of a new reaction mixture, similar to the primary amplification but containing the primers ADHEX2F and ADHEX1R, using the same cycle conditions. After the amplification was completed, $5 \mu \mathrm{L}$ of the reaction mixture was analyzed on $1 \%$ agarose gel containing ethidium bromide and was visualized under UV light to detect an expected product of $168 \mathrm{bp}$.

Cell culture: Cell culture was performed on continuous human epithelial carcinoma cell lines (HEP-2). Tubes with $80 \%$ confluent monolayers were inoculated with $0.2 \mathrm{~mL}$ of homogenized samples treated with antibiotics and antifungals. The inoculum was absorbed to the monolayer in the space of one hour at $37^{\circ} \mathrm{C}$. Cells were fed with $2 \mathrm{~mL}$ of $2 \%$ fetal calf serum in Basal Medium Eagle (Sigma Inc), and monitored to detect the cytopathic effect (CPE) for four weeks. When CPE was observed, the monolayer was scraped and tested for AdV antigen by IF with a specific monoclonal antibody. Tubes were discarded as negative after 30 days without CPE.

Ethics: Clinical and epidemiological data from AdV infected pediatric patients were revised from medical records. The Ethics Review Board of the HC-UFPR approved the study.

\section{RESULTS}

A total of 381 samples were analyzed during 2008. Two hundred twenty-nine $(229 / 381-34 \%)$ samples tested were positive to one or more respiratory viruses (Fig. 1).

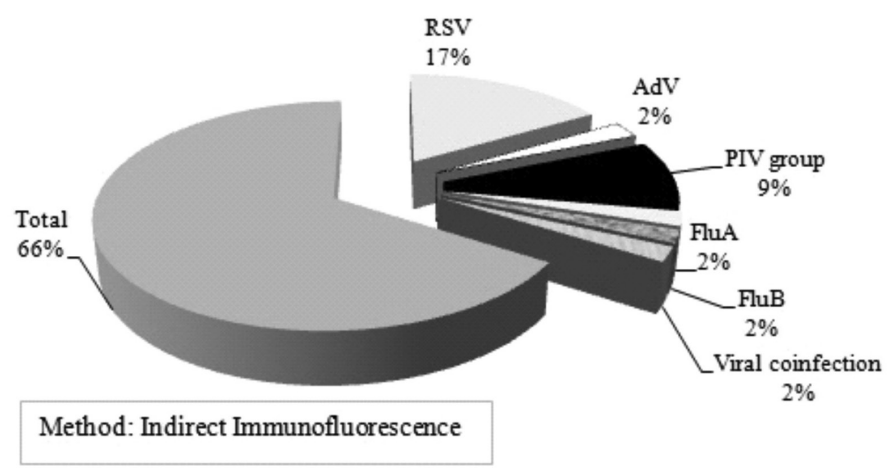

Fig. 1 - Respiratory viral detection in patients hospitalized by acute respiratory infections during 2008 year - HC/UFPR (HC/UFPR: Hospital de Clínicas/Universidade Federal do Paraná).

Considering the results of the research of $\mathrm{AdV}, \mathrm{PCR}$ was positive in $38 / 381(10 \%)$ samples, IF was positive in $10 / 381(2.6 \%)$ and indeterminate in $2 / 381(0.5 \%)$. A total of 46 indeterminate or positive samples (four samples were positive by PCR and IFI) were inoculated in cell culture, and AdV was isolated in 11 (24\%) cases (Fig. 2). Nine $(9 / 46-19.5 \%)$ patients were undergoing bone marrow transplantation and other $37 / 46(80.5 \%)$ were hospitalized in pediatric units. Records from 37 pediatric patients were reviewed.

The majority of the children were male $(59.4 \%)$, and $81 \%$ were under twenty-four months old. Fever, cough and tachypnea were the most commonly reported clinical manifestations, and the most frequent 


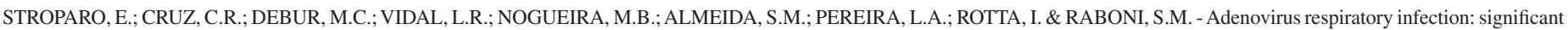
increase in diagnosIs using PCR comparing with antigen detection and culture methods. Rev. Inst. Med. Trop. Sao Paulo, 52(6): 317-21, 2010.

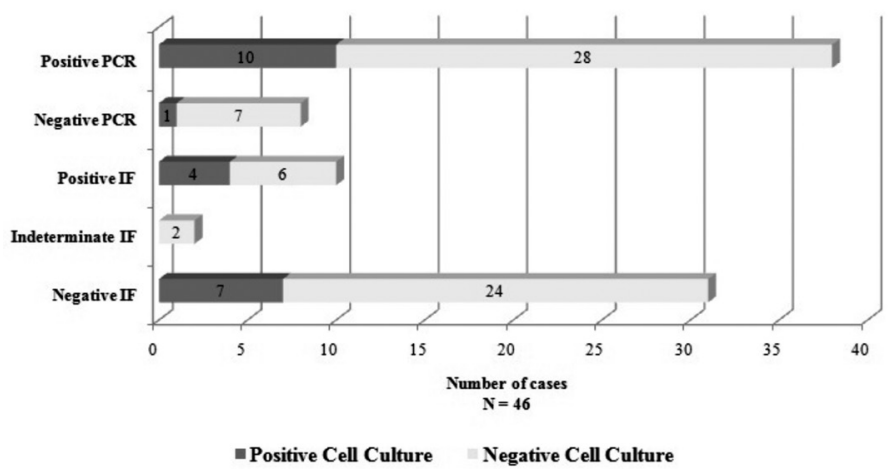

Fig. 2 - Comparison of immunofluorescence assay, PCR and cell culture to detect adenovirus in patients with respiratory infections*. (*Adenovirus indeterminate and positive samples by immunofluorescence (IF) assay and/or PCR are compared to cell culture results).

medical diagnoses were bronchopneumonia and tracheobronchitis. One or more risk factors or comorbidities were present in $64.9 \%$ of patients, mainly represented by prematurity, pulmonary, genetic and cardiac disorders. Among genetic disorders, Down syndrome was the most frequent, with four patients. Epidemiological and clinical data from pediatric patients are shown in Table 1.

Eleven (11/37 - 29.7\%) patients required admission to intensive care unit for a median time of nine days (range from four to 19 days), and $19 \%$ (7/37) patients needed mechanical ventilation. Antibiotics were used in $67.6 \%$ (25/37), oxygen in $86.5 \%$ (32/37) and the median hospital stay was seven days (with a total range of two to 85 days). Blood cultures were collected from 36 patients. Of these, 94.4\% (34/36) were negative; one was positive for Pseudomonas aeruginosa (just the child admitted to sepsis); and another was positive for coagulase negative staphylococcus (probably by contamination). The overall mortality rate was $5 \%$.

The presence of viral coinfection was $21.6 \%$ (8/37): four cases of coinfection with Adenovirus/Enterovirus, two with Adenovirus/Respiratory syncytial virus, and two with Adenovirus/Parainfluenza 3 virus.

\section{DISCUSSION}

Despite its association with severe respiratory infections, the use of specific diagnostic laboratory tests for viral agents in the case of ARIs is limited due to financial and technical problems, or due to the fact that viruses are underestimated as agents of respiratory infections requiring hospitalization ${ }^{22}$. In the present study, one-third of the samples tested were positive for one or more respiratory virus analyzed by antigen detection, and we demonstrated an increase of $2 \%$ to $10 \%$ in the detection of AdV in clinical samples, comparing the results of IF and PCR. The cell culture results demonstrated a higher sensitivity than IF, and a lower sensitivity than PCR results, as was expected. The results were consistent for the majority of the tests. Nevertheless, some samples have positive IF with negative isolation and PCR. This may have occurred because virus isolation and PCR were not performed in the same period of the IF, and consequently there was a loss of proper clinical material after freezing, or else, could have occurred due to a false-positive IF. False-positive results must be considered when the reader found cells with characteristic coloration, and when the result was not confirmed by other methods. It is important to mention that
Table 1

Pediatric patients infected with adenovirus: demographic and clinical data

\begin{tabular}{lll}
\hline Data & N & $\%$ \\
\hline
\end{tabular}

Age range

$\begin{array}{lcc}<6 \text { months } & 9 & 24.3 \\ >6 \text { months }-12 \text { months } & 12 & 32.4 \\ >12 \text { months }-24 \text { months } & 9 & 24.3 \\ >24 \text { months } & 7 & 18.9\end{array}$

\section{Gender}

Male

59.4

Female

Diagnosis

Bronchopneumonia 14

Bronchitis

Laryngotracheitis

Acute bronchiolitis

5.4

Asthma

Metabolic disorder

Sepsis

Febril neutropenia

\section{Symptoms}

Cough

Tachypnea

Fever

Wheezing

Vomiting

Cyanosis

16.2

Diarrhea

Apnea

Risk factors/comorbidity

Yes

No

Genetic disorder*

$7 / 24$

18.9

Pulmonary disorder

Cardiac disorder

Prematurity

Neurologic disorder

HIV

Other**

$4 / 24$

*Down Syndrome: 4; **Hematologic disorder: 1; Leukemia: 1; Endocrinopathy: 1; Nephopathy:1. 
STROPARO, E.; CRUZ, C.R.; DEBUR, M.C.; VIDAL, L.R.; NOGUEIRA, M.B.; ALMEIDA, S.M.; PEREIRA, L.A.; ROTTA, I. \& RABONI, S.M. - Adenovirus respiratory infection: significant increase in diagnosIs using PCR comparing with antigen detection and culture methods. Rev. Inst. Med. Trop. Sao Paulo, 52(6): 317-21, 2010.

all the slides are submitted to double-blind reading by two researchers. Even so, reading error may be considered.

Detection of viral antigen by IF is fast, but often lacks sensitivity in detecting some viruses, and its confirmation by viral culture may sometimes be necessary ${ }^{10}$. Viral culture was recognized as the gold standard for testing viral respiratory pathogens. However, this method is generally slow, often requiring more than 14 days for delivery of results ${ }^{24}$. Although the combination of these two techniques can increase the percentage of positive results, it has been reported that a significant number of specimens remains negative despite clinical and epidemiological suspicion of viral infection ${ }^{9,12,13}$. Over the past years, there have been an increasing number of reports on the progress of molecular biology techniques for the diagnosis of viral infections; these will probably be the gold standard methods currently employed in routine laboratory tests. Molecular techniques have significantly contributed to the rapid identification of the viral agent associated with acute respiratory infections, allowing for the quick adoption of therapeutic measures and preventive strategies to avoid the spread of the disease with high transmissibility ${ }^{20,23}$.

Record analysis showed the clinical and demographic profile of AdV infected patients: the infection occurred mainly in male pediatric patients, most of them less than two years of age; and in 33\% of the cases, patients showed no risk factors, other than their young age. Regardless of the low mortality rate observed ( $5 \%$ ), twenty-seven percent of the patients needed intensive care, which corroborates the seriousness of these infections. Despite the wide use of antibiotics, bacterial infection was confirmed in only one patient. However, viral coinfection was detected in $20 \%$ of the adenovirus positive samples, which, accordingly, previous reports may have contributed to high hospital admission rates ${ }^{2,5,25}$.

The introduction of molecular methods in routine diagnosis has shown that $\mathrm{AdV}$ is more frequently involved with severe respiratory infections in pediatric patients than previous studies based on antigen detection and cell culture methods have indicated. Rapid and sensitive molecular methods used to identify AdV infection are needed because of their rapid spread and high hospital mortality rate. In addition, the use of molecular tests to detect respiratory viruses in routine laboratory investigations in hospitalized patients will assist in the introduction of preventive measures to avoid viruses' dissemination and to minimize the misuse of broad spectrum antibiotics in this environment.

\section{RESUMO}

\section{Infecção respiratória aguda por adenovirus - comparação dos métodos de PCR e imunofluorescência indireta para o seu diagnóstico e dados clínicos dos pacientes infectados}

Infecções respiratórias por Adenovírus (ADV) são geralmente descritas associadas com alta mortalidade. O diagnóstico laboratorial é essencial para o estabelecimento da terapêutica adequada e para orientar a implantação de medidas preventivas evitando a propagação da infecção. Com o objetivo de analisar a sensibilidade e a especificidade dos métodos de avaliação de diagnóstico laboratorial, foi comparada a detecção de antígeno por imunofluorescência indireta (IF) com a reação em cadeia da polimerase específica (PCR) para detectar AdV em amostras respiratórias coletadas de pacientes internados com doença respiratória aguda. As amostras com resultados positivos foram inoculadas em cultura celular. Foram analisadas 381 amostras da secreção nasofaríngea coletadas durante o ano de 2008, das quais 2,6\% foram positivas pela IF e $10 \%$ pela PCR, isolamento positivo foi obtido em $40 \%$ e $26 \%$ dos casos positivos pelos testes anteriores, respectivamente. A maioria dos pacientes infectados eram crianças com menos de seis meses de idade, $\mathrm{e}$ apesar do fato de que um número significativo de pacientes necessitou de cuidados intensivos, a taxa de mortalidade foi baixa (5\%). Em conclusão, os métodos moleculares são úteis para o diagnóstico rápido de infecções por adenovírus com maior sensibilidade do que a detecção do antígeno, a sua introdução na rotina permitiu um aumento significativo no diagnóstico de infecções por adenovírus.

\section{REFERENCES}

1. Avellón A, Pérez P, Aguilar JC, Lejarazu RO, Echevarría JE. Rapid and sensitive diagnosis of human adenovirus infections by a generic polymerase chain reaction. J Virol Methods. 2001;92:113-20.

2. Bonzel L, Tenenbaum T, Schroten H, Schildgen O, Schweitzer-Krantz S, Adams $\mathrm{O}$. Frequent detection of viral coinfection in children hospitalized with acute respiratory tract infection using real-time polymerase chain reaction. Pediatr Infect Dis. 2008;27:589-94

3. Carrigan DR. Adenovirus infections in immunocompromised patients. Am J Med. 1997;102:71-4.

4. Casas I, Powell L, Klapper PE, Cleator GM. New method for the extraction of viral RNA and DNA from cerebrospinal fluid for use in the polymerase chain reaction assay. J Virol Methods. 1995;53:25-36.

5. Cilla G, Oñate E, Perez-Yarza EG, Montes M, Vicente D. Perez-Trallero E. Viruses in community-acquired pneumonia in children aged less than 3 years old: high rate of viral coinfection. J Med Virol. 2008;80:1843-9.

6. De Jong JC, Wermenbol AG, Verweig-Uijterwaal MW, Slaterus KW, Wertheim-Van Dillen P, Van Doornum GJ. et al. Adenoviruses from human immunodeficiency virusinfected individuals, including two strains that represent new candidate serotypes Ad50 and Ad51 of species B1 and D, respectively. J Clin Microbiol. 1999;37:3940-5.

7. Ebner K, Suda M, Watzinger F, Lion T. Molecular detection and quantitative analysis of the entire spectrum of human adenoviruses by a two-reaction real-time PCR assay. J Clin Microbiol. 2005;43:3049-53.

8. Echavarria M, Maldonado D, Elbert G. Videla C, Rappaport R, Carballal G. Use of PCR to demonstrate presence of adenovirus species B, C, or F as well as coinfection with two adenovirus species in children with flu-like symptoms. J Clin Microbiol. 2006;44:625-7.

9. Ellis JS, Fleming DM, Zambon MC. Multiplex reverse transcription-PCR for surveillance of influenza A and B viruses in England and Wales in 1995 and 1996. J Clin Microbiol. 1997;35:2076-82.

10. Fan J, Henrickson KJ. Rapid diagnosis of human parainfluenza virus type 1 infection by quantitative reverse transcription-PCR-enzyme hybridization assay. J Clin Microbiol. 1996;34:1914-7.

11. Foy H. Adenoviruses. In: Evans AS, Kaslow RA, editors. Viral infections in humans. $4^{\text {th }}$ ed. New York: Plenum Medical Book Company; 1997. p. 119-38.

12. Freymuth F, Eugene G, Vabret A, Petijean J, Gennetay E, Brouard J, et al. Detection of respiratory syncytial virus by reverse transcription-PCR and hybridization with a DNA enzyme immunoassay. J Clin Microbiol. 1995;33:3352-5.

13. Gilbert LL, Dakhama A, Bone BM, Thomas EE, Hegele RG. Diagnosis of viral respiratory tract infections in children by using a reverse transcription-PCR panel. J Clin Microbiol. 1996;34:140-3. 


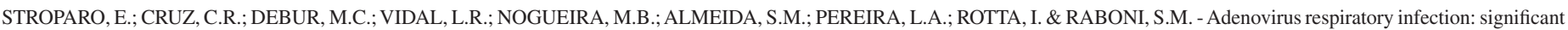
increase in diagnosIs using PCR comparing with antigen detection and culture methods. Rev. Inst. Med. Trop. Sao Paulo, 52(6): 317-21, 2010.

14. Heim A, Ebne C, Harste G, Pring-Akerblom P. Rapid and quantitative detection of human adenovirus DNA by real-time PCR. J Med Virol. 2003;70:228-39.

15. Hierholzer JC. Adenoviruses in the immunocompromised host. Clin Microbiol Rev. 1992;5:262-74.

16. Hong JY, Lee HJ, Piedra PA, Choi EH, Park KH, Koh YY, et al. Lower respiratory tract infections due to adenovirus in hospitalized Korean children: epidemiology, clinical features, and prognosis. Clin Infect Dis. 2001;32:1423-9.

17. Howard DS, Phillips IGL, Reece DE, Munn RK, Henslee-Downey J, Pittard M, et al. Adenovirus infections in hematopoietic stem cell transplant recipients. Clin Infect Dis. 1999;29:1494-501.

18. Horwitz MS. Adenoviruses. In: Fields BN, Knipe DM, Howley PM, editors. Fields Virology. $3^{\text {rd }}$ ed. Philadelphia: Lippincott-Raven; 1996. p. 2149-71.

19. Kojaoghlanian T, Flomenberg P, Horwitz MS. The impact of adenovirus infection on the immunocompromised host. Rev Med Virol. 2003;13:155-71.

20. Kuypers J, Wright N, Ferrenberg J, Huang M-L, Cent A, Corey L, et al. Comparison of real-time PCR assays with fluorescent-antibody assays for diagnosis of respiratory virus infections in children. J Clin Microbiol. 2006;44:2382-8.

21. Morris DJ, Cooper RJ, Barr T, Bailey AS. Polymerase chain reaction for rapid diagnosis of respiratory adenovirus infection. J Infect. 1996;32:113-7.

22. Moura FEA, Borges LC, Souza LSF, Ribeiro DH, Siqueira MM, Ramos EA. Estudo de infecções respiratórias agudas virais em crianças atendidas em um centro pediátrico em Salvador (BA). J Bras Patol Med Lab. 2003;39:275-82.

23. Nolte F, Marshall DJ, Rasberry C, Schievelbein S, Banks GG, Storch GA, et al. MultiCode-PLx system for multiplexed detection of seventeen respiratory viruses. J Clin Microbiol. 2007;45:2779-86.
24. Paton AW, Paton JC, Lawrrence AJ, Goldwater PN, Harris RJ. Rapid detection of respiratory syncytial virus in nasopharyngeal aspirates by reverse transcription and polymerase chain reaction amplification. J Clin Microbiol. 1992;30:901-4.

25. Peng D, Zahao D, Liu J, Wang X, Yang K, Xicheng H, et al. Multipathogen infections in hospitalized children with acute respiratory infections. J Virol. 2009;6:155

26. Shirali GS, Ni J, Chinnock RE, Johnston JK, Rosenthal GL, Bowles NE, et al. Association of viral genome with graft loss in children after cardiac transplantation. N Engl J Med. 2001;344:1498-503.

27. Teramura T, Naya M, Yoshihara T, Kanoch G, Morimoto A, Imashuku S. Adenovira infection in hematopoietic stem cell transplantation: early diagnosis with quantitative detection of the viral genome in serum and urine. Bone Marrow Transplant 2004:33:87-92.

28. Vidal LR, Siqueira MM, Nogueira MB, Raboni SM, Pereira LA, Takahashi GR, et $a l$. The epidemiology and antigenic characterization of influenza viruses isolated in Curitiba, South Brazil. Mem Inst Oswaldo Cruz. 2008;103:180-5.

29. Yusuf U, Hale GA, Carr J, Gu Z, Benaim E, Woodard P. et al. Cidofovir for the treatment of adenoviral infection in pediatric hematopoietic stem cell transplant patients. Transplantation. 2006;81:1398-404

30. Wadell G. Adenoviruses. In: Zuckerman AJ, Banatvala JE, Pattison JR, editors. Principles and practice of clinical Virology. $4^{\text {th }}$ ed. Chichester: Wiley; 1999. p. 307-27.

Received: 14 July 2010

Accepted: 8 October 2010 